\title{
Livelihoods Research Findings and Agriculture-led Growth
}

\author{
Godfrey Bahilgwa, Ntengua Mdoe and Frank Ellis
}

\section{Introduction}

The findings of livelihoods research conducted in East Africa and Malawi demonstrate that the role of agriculture in contributing to poverty reduction in sub-Sahara African countries is rather more complicated than the apparently straightforward mechanisms portrayed by enthusiasts for agriculture-led growth strategies in the region. Rural livelihoods are diverse and founded on interdependencies between rural and urban areas. These interdependencies have deepened since market liberalisation in the 1980s due to increased price risk, rising input prices relative to output prices, detrimental HIV/AIDS effects on labour and other asset availabilities, environmental deterioration and continuing farm subdivision at inheritance.

The presence of these adverse factors and trends in agriculture means that poverty and vulnerability are associated more with undue reliance on farming than the converse. Those farms achieving yield growth do so due to cash resources generated from non-farm and urban activities, rather than being the origin of growth in such activities as proposed in the agriculture-led growth models. For those farm families that lack non-farm options, subsistence behaviour for food security is the norm. Indeed, in some rural areas it is probable that the proportion of food staples consumed in the home rather than sold in the market has increased rather than diminished over the past two decades, shrinking the monetised economy and increasing vulnerability as a consequence.

The livelihoods research reported here was called LADDER and its fieldwork was conducted in $2001 .{ }^{1}$ The main findings and policy implications have been published elsewhere (Ellis and Bahiigwa 2003;
Ellis and Mdoe 2003; Ellis et al. 2003; Ellis and Freeman 2004, 2005). Nevertheless there remains plenty of scope for applying those findings to address different debates, and that is what is done here with respect to the role of agriculture in poverty reduction in sub-Saharan Africa. The article begins by providing a brief summary of the research context. This is followed by considering key findings in two case-study countries: Uganda and Tanzania. A further section draws together cross-country qualitative and quantitative findings in order to interpret their implications for the agriculture-led poverty reduction hypothesis. Finally, the article hazards some remarks about poverty-reduction approaches in Africa that build more on people's observable livelihood strategies and less on idealised notions about the prospects for, and benefits of, agriculture-led growth.

\section{Livelihoods research in PRSP contexts}

The research underlying this article was initiated in 2000 , shortly after Poverty Reduction Strategy Papers (PRSPs) replaced structural adjustment programmes as the overarching framework governing donor-government relations in low-income countries. The research had two main objectives: the first was to achieve a better understanding of the constraints and opportunities characterising rural livelihoods in a set of case-study countries, utilising the sustainable livelihoods framework and the second was to make the micro-macro links between household livelihoods and the macro policy contexts put in place by the advent of PRSPs.

The two countries selected for more detailed treatment here (Uganda and Tanzania), were both

IDS Bulletin Vol 36 No 2 June 2005 @ Institute of Development Studies 


\begin{tabular}{lllllll} 
Table 1: Selected Attributes of Rural Livelihoods by Income Quartile, Uganda Sample \\
\hline Attribute & Unit & \multicolumn{2}{l}{ Income quartiles } & & & Mean \\
\hline & & I & II & III & IV & (n=315) \\
\hline Land owned & Ha & 0.59 & 1.05 & 1.96 & 2.15 & 1.43 \\
Livestock & CEU & 0.77 & 0.87 & 2.01 & 3.15 & 1.70 \\
Subsistence & \% Matooke output & 74.8 & 75.9 & 70.2 & 70.0 & 72.2 \\
Subsistence & \% HH income & 32.9 & 32.1 & 29.2 & 23.5 & 25.8 \\
Agriculture & \% HH income & 51.3 & 58.1 & 57.8 & 41.7 & 47.8 \\
Business & \% HH income & 24.5 & 16.3 & 24.8 & 45.5 & 36.4 \\
Productivity & Net agric. Output & 232.6 & 380.4 & 523.5 & 863.3 & 575.9 \\
& (TShs'000/ha) & & & & &
\end{tabular}

Source: sample survey conducted in nine villages January-April 2001.

relatively early among sub-Sahara African countries in the completion of first round PRSPs and their acceptance by the international financial institutions as the basis for debt relief under the enhanced HIPC (Heavily Indebted Poor Countries) initiative. The publication dates of first round PRSPs were March 2000 (Uganda) and October 2000 (Tanzania) and the "completion points" for HIPC debt relief were May 2000 and November 2001, respectively. Both countries are therefore already into second round PRSP territory, with Uganda having completed its third Poverty Eradication Action Plan (PEAP) during 2004.

The incidence of poverty in Uganda is estimated to have fallen rapidly during the 1990s, followed by some levelling off or reversal between 1999/2000 and 2002/03. A series of nationally representative household surveys showed poverty declining from 56 per cent in 1992 to 44 per cent in 1997 and 34 per cent in 1999 (Appleton 1999, 2001). However, data for 2002/03 shows a rise to 38 per cent (Uganda 2003). The extent to which this reversal reflects real underlying circumstances or is an artefact of measurement inaccuracies is unclear. At any rate, the 2002/03 survey data gives a poverty rate of 42 per cent in rural and 12 per cent in urban areas, these indicators having declined from 60 per cent and 28 per cent in 1992, respectively.

Surprisingly, perhaps, given vastly different political and economic histories, the poverty data for Tanzania in the early 2000s does not differ much from Uganda (Tanzania 2002). The estimates for 2000/01 are 36 per cent overall poverty and 39 per cent poverty incidence in rural areas. For urban areas, there is a difference between Dar es Salaam (18 per cent) and other urban areas (26 per cent). The chief difference from Uganda is that these indices did not decline much during the 1990s in the Tanzania case, and indeed there was some debate at the time the data was released as to whether they had declined at all.

The considerably higher incidence of rural poverty in countries like Uganda and Tanzania leads most analysts to conclude that poverty should be tackled in rural areas. The agriculture-led growth hypothesis taps neatly into this opening. However, this proposition is open to challenge, and the livelihoods findings described below provide some basis for a counter argument. Specifically, it is worth posing the question if urban areas and capital cities are doing a better job at reducing poverty than rural areas, then why not go with the flow of growth and support urban rather than rural growth? In other words, it might make more sense to encourage human mobility to the dynamic areas of national economies than to support areas that are in inexorable stagnation or decline.

Uganda and Tanzania were two of four countries in which LADDER worked; the other two being Kenya and Malawi. The same research methods were applied across all countries and comprised a mixture of qualitative and quantitative methods; the qualitative component addressing the policy and institutional context of livelihoods and changing livelihood circumstances at community level, and the quantitative component addressing assets, activities, incomes and vulnerability factors at household level. Research sites within and across 
the case-study countries were purposively selected in order to capture food-based farming systems representing the majority platform of rural livelihoods under a wide variety of differing agroecological conditions. Overall, 1,345 households in 37 villages in nine districts across the four countries were researched.

\section{Uganda}

Research in Uganda was conducted in Mbale, Kamuli and Mubende districts, describing an arc across the south-centre of the country. Three villages were selected in each district in order to represent differing agro-ecological and other circumstances. Of the nine research villages, five represented the coffee-banana production system that predominates in the densely settled regions of Uganda, three were lakeside villages that combined fishing with food crop and livestock farming, and one represented maize and root crop farming. The key findings of the Uganda research were as follows:

- Small and declining farm size overall: average farm size in the sample was $1.43 \mathrm{ha}$, and farm subdivision at inheritance the norm

- Low asset status at the bottom of the income distribution: the lowest income quartile owned on average 0.6 ha of land and no livestock to speak of except a few chickens

- High self-consumption of key food crops, overall and especially for poor families

- Declining share of subsistence consumption in total income as income rises, decreasing vulnerability through engagement in the money economy

- Prevalence of diverse livelihoods combining farming with non-farm activities such that agriculture accounted for 48 per cent of an average household income for the sample overall ${ }^{2}$

- Rising significance of non-farm self-employment income towards the top end of the income distribution

- Rising yields per hectare associated with high non-farm earnings.

These features are summarised in Table 1. Note that livestock holdings are measured in cattle equivalent units (CEUs). These are calculated from mean price ratios between different livestock types such that if a goat has a market value of one-fifth of a cow, then five goats are required to generate one
CEU. In reality, few households below the top quartile own any cattle at all, and the only livestock owned by the poorest quartile are likely to be chickens. Lack of livestock is a basic feature of being poor in Uganda as elsewhere in the region (Ellis and Freeman 2004). The data for subsistence matooke (cooking bananas) consumption refers to the proportion of matooke produced that is self-consumed by the household rather than sold in the market. Those for subsistence in household $(\mathrm{HH})$ income refers to the value of own consumption of matooke and other self-consumed farm outputs as a share of total household income. Finally, net agricultural output in value terms is calculated on a per hectare basis as a measure of agricultural productivity. For these purposes, agriculture is defined as crop and livestock production, and excludes fishing, which was a specialised occupation in the Kamuli district villages.

\section{Tanzania}

Livelihoods research in Tanzania was conducted in the Kilosa and Morogoro rural districts of the Morogoro region in four different research locations representing varying agro-ecological conditions connected to the central theme of livelihoods based on mixed food crop farming. The four locations comprised three sub-villages representing smallfarm irrigated food crops, two sub-villages representing rain-fed maize production; two subvillages representing upland vegetable and fruit production; and three sub-villages representing mixed food crop farming in a remote location. Altogether, 350 households were interviewed in these four locations (Ellis and Mdoe 2003: 1371).

With striking similarities to Uganda, the main attributes about gaining a living in the sample areas of rural Tanzania were:

- Small and declining farm size overall: average farm size in the sample was 1.54 ha, eroding over time in densely settled locations

- Low asset status at the bottom of the income distribution: landlessness was prevalent in several of the study sites, and the lowest income quartile farmed on average under 1 ha, and owned less than one-sixth of the livestock holdings of the top income quartile

- High self-consumption of key food crops, overall and especially for poor families

- Steeply declining share of subsistence consumption in total income across the income ranges 


\begin{tabular}{lllllll}
\multicolumn{2}{l}{ Table 2: Selected Attributes of Rural Livelihoods by Income Quartile, Tanzania Sample } \\
\hline Attribute & Unit & \multicolumn{2}{l}{ Income quartiles } & Mean & & \\
\hline & & I & II & III & IV & ( \\
& & 0.94 & 1.39 & 1.70 & 2.13 & 1.54 \\
\hline Land owned & Ha & 0.28 & 0.94 & 0.48 & 1.92 & 0.89 \\
Livestock & CEU & 81.7 & 80.4 & 80.8 & 67.6 & 77.8 \\
Subsistence & \% Maize output & 39.1 & 28.7 & 22.1 & 14.1 & 18.6 \\
Subsistence & \% HH income & 67.7 & 63.3 & 55.7 & 42.6 & 49.7 \\
Agriculture & \% HH income & 11.5 & 23.7 & 29.3 & 44.0 & 36.1 \\
Business & \% HH income & 72.3 & 95.8 & 138.8 & 339.1 & 184.0 \\
Productivity & Net agric. Output & & & & &
\end{tabular}

Source: Sample survey conducted in ten sub-villages in May-August 2001.

- Prevalence of diverse livelihoods combining farming with non-farm activities such that on average 50 per cent of household incomes derived from non-farm sources

- Steeply rising significance of non-farm selfemployment income across the income ranges

- Rising yields/ha associated with high non-farm earnings.

These features are summarised in Table 2 and Figure 1 . The same definitions of the data apply as for the Uganda case described above, only in this instance maize is the staple food crop chosen to illustrate subsistence behaviour across the income ranges rather than matooke. Even more so than for Uganda, the Tanzania sample demonstrates the skewness of livestock holdings towards the top of the rural income distribution, the steep decline in overall subsistence across the income ranges, and the rise in net agricultural output per hectare, such that the top income quartile realises nearly five times the product per unit of land of the bottom income quartile.

The Tanzania sample provides an excellent illustration of the relationship between non-farm income share and net agricultural output per hectare, as summarised in Figure 1. While the relative reliance on agriculture declines across the income ranges from 68 per cent for the poorest quartile, to 43 per cent for the richest, agricultural productivity rises so that it is five times higher for the top quartile compared with the bottom quartile. It is notable that the share of livestock in the income portfolio of the top quartile more than doubles compared with the bottom quartile, and the share of non-farm business income quadruples from 11 to 44 per cent of the income portfolio.

\section{Implications of the findings for agriculture-led poverty reduction}

If any single finding of the livelihoods research was to be singled out as pertinent to the agriculture-led poverty reduction hypothesis, it is this close correlation between the relative importance of nonfarm earnings and the rise in net agricultural output per hectare. The Uganda and Tanzania findings on this were also reproduced in Malawi and Kenya (Ellis and Freeman 2004). This is not a new finding, nor can it be separated from complementary observations concerning the inter-relationship between rural and urban areas that characterise livelihood patterns in Africa (e.g. Evans and Ngau 1991; Tiffen et al. 1994; Bryceson 2005). It seems to reverse the argument of the agriculture-led growth school in which the starting point is yield gains in agriculture and the end point is poverty reduction led by the linkages and multipliers of agricultural growth (Mellor 1976; Delgado et al. 1998; IFPRI 2002).

The agriculture-led growth position also has other flaws that emerge from broader perspectives on its arguments consistent with qualitative and quantitative observations on the ground. First, real international prices of agricultural commodities have halved since the early 1980s, partly, but not only, due to industrial country farm support policies and export subsidies (Maxwell 2004). Second, domestic markets for food grains in fact turn out 
Figure 1: Comparison of Share of Agriculture in Total Income and Net Agricultural Output/ha, Tanzania Sample, by Income Quartile

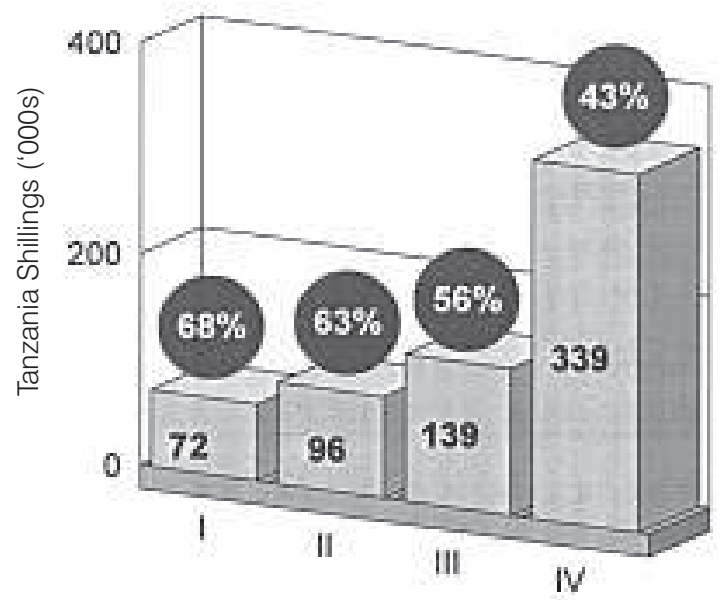

Note: Share of agriculture displayed as percentage (\%) data in the circles; net agricultural output/ha in TShs'000s/ha on the bar graph.

to be rather limited: in an average-sized African economy it only takes a reasonably good harvest to occur of a food staple like maize for prices to decline to levels that make farming relatively unattractive among competing activities. Complaints about low output prices and high fertiliser prices were ubiquitous in the case-study research areas. Third, the Asian Green Revolution of the 1970s, which tends to be invoked as the touchstone of the agriculture-led growth position, was predicated on comprehensive agricultural support policies that were dismantled in Africa during the structural adjustment period of the 1980s and 1990s. In those days there were fixed prices, floor prices, buffer stocks, fertiliser subsidies, credit subsidies and public irrigation schemes, all paid for by the state or by donors.

The outcome of these considerations is that we cannot be certain that the current promotion of an agricultural growth solution to rural poverty in Africa will have the desirable consequences that are predicted for it. It is unclear why the startlingly high poverty reduction returns to agricultural research (Thirtle et al. 2003) and large predicted growth multipliers attributed to rising yields in agriculture (Delgado et al. 1998) have resulted in so little visible effect in Africa, if these models are based on real empirical trends and outcomes. When reality on the ground in rural areas of African countries departs so very significantly from several decades of promoting the idea that agriculture can bring Africans out of poverty, then we have to ask what it is about those propositions that fail to predict what actually occurs in practice.

Perhaps what people do might be a more reliable guide to the underlying pressures and opportunities they confront than adherence to a closely argued position that seems increasingly at odds with people's actions. And what people do is to engage in ever more complex and adaptable interactions across sectors involving mobility of varying kinds, distances and durations. In learning lessons from history, it is mobility that is possibly a more powerful factor in rapid economic change than the primacy of agriculture touted by the agriculture-led growth school. Indeed, there may be a serious flaw in the notion, prevalent in development policy for the past two decades, that the best way of addressing poverty is to support poor people at their static residential location; in this instance, on the farm, and in rural areas. Rather, a more useful approach may be to build on those places in the national economy where growth is most evident, ensuring that infrastructure, transport, communications and skills are available to contribute to that growth process wherever it occurs. 
Returning to the case-study countries, Uganda and Tanzania, the growth of their capital cities, Kampala and Dar es Salaam, perhaps offer better prospects for rapid poverty reduction than agriculture. However, this growth is likely to be prematurely curtailed by failure to support the urban infrastructure necessary to fuel the growth process. With heads full of populist visions of prosperous peasants, donors overlook urban growth constraints and encourage governments to

\section{Notes}

1. LADDER, Livelihoods and Diversification Directions Explored by Research, was a research programme funded from 2000-04 by the then Policy Research Programme of the Department for International Development (DFID), with a contribution to the work in Kenya made by the United Nations Development Program (UNDP). The

\section{References}

Allison, E., 2005, 'The fisheries sector, livelihoods and poverty reduction in Eastern and Southern Africa', in F. Ellis and H.A. Freeman (eds), Rural Livelihoods and Poverty Reduction Policies, London: Routledge: 256-73

Appleton, S., 2001, 'Poverty reduction during growth: the case of Uganda, 1992-2000', mimeo, University of Nottingham

Appleton, S., 1999, 'Changes in poverty in Uganda 1992-97', mimeo, Centre for the Study of African Economies, Oxford

Bryceson, D.F., 2005, 'Rural livelihoods and agrarian change in Sub-Saharan Africa: processes and policies', in F. Ellis and H.A. Freeman (eds), Rural Livelihoods and Poverty Reduction Policies, London: Routledge: 48-61

Delgado, C., Hopkins, J. and Kelly, V., 1998, 'Agricultural growth linkages in sub-Saharan Africa', Research Report 107, Washington, D.C.: International Food Policy Research Institute

Ellis, F. and Bahiigwa, G., 2003, 'Livelihoods and poverty reduction in Uganda', World Development, Vol 31 No 6: 997-1013

Ellis, F. and Freeman, H.A. (eds), 2005, Rural Livelihoods and Poverty Reduction Policies, London: Routledge

Ellis, F. and Freeman, H.A. (eds), 2004, 'Rural livelihoods and poverty reduction strategies in four African countries', Journal of Development Studies, Vol 40 No 4: 1-30

Ellis, F. and Mdoe, N., 2003, 'Rural livelihoods and poverty reduction in Tanzania', World Development, Vol 31 No 8: 1367-84 pour money into the countryside. It should not be necessary to point out that conditions in agriculture will automatically improve if rapid growth in food demand occurs in fast-growing cities. Finally, seeking to achieve a more balanced view of rural-urban interactions does not of course invalidate efforts to improve agriculture; what it does is redress a currently reckless one-sided interpretation of the drivers of poverty reduction in sub-Sahara African economies.

findings and views expressed here are solely the responsibility of the authors and are not attributable to DFID or UNDP.

2. The share of agriculture (crop and livestock production) and self-employment is calculated excluding fishing as a specialised occupation in three villages. For analysis of the role of fishing in livelihoods, see Allison (2005).

Ellis, F., Kutengule, M. and Nyasulu, A., 2003, 'Livelihoods and rural poverty reduction in Malawi', World Development, Vol 31 No 9: 1495-510

Evans, H.E. and Ngau, P., 1991, 'Rural-urban relations, household income diversification and agricultural productivity', Development and Change, Vol 22 No 3: 519-45

IFPRI, 2002, 'Fighting famine in Southern Africa: steps out of the crisis', IFPRI Briefing Paper, Washington, D.C.: International Food Policy Research Institute

Maxwell, S., 2004, Launching the DFID Consultation 'New Directions of Agriculture in Reducing Poverty', http://dfid-agriculture-consultation.nri.org (accessed 20 April 2004)

Mellor, J.W., 1976, The New Economics of Growth, Ithaca, New York: Cornell University Press

Tanzania, 2002, Household Budget Survey 2000/01: Key Findings, Dar es Salaam: National Bureau of Statistics, July

Tiffen, M., Mortimore, M. and Gichuki, F., 1994, More People, Less Erosion: Environmental Recovery in Kenya, Chichester: John Wiley

Thirtle, C., Lin, L. and Piesse, J., 2003, 'The impact of research-led agricultural productivity growth on poverty reduction in Africa, Asia and Latin America', World Development, Vol 31 No 12: 1959-75

Uganda, 2003, Uganda National Household Survey 2002/2003: Report on the Socio-Economic Survey, Entebbe: Uganda Bureau of Statistics, November 